Tugas Individu

Mata Kuliah: Pendidikan Matematika II

Dosen: Jusmawati, S.Pd.,M.Pd

Volume Balok

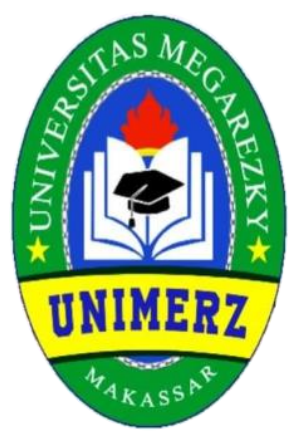

SEMESTER V

KAMSINAH

18093188206004

FAKULTAS KEGURUAN DAN ILMU PENDIDIKAN (FKIP)

PENDIDIKAN GURU SEKOLAH DASAR (PGSD)

UNIVERSITAS MEGAREZKY

2020 


\section{KATA PENGANTAR}

Puji syukur kita panjatkan atas kehadirat Allah SWT karena berkat rahmat dan hidayah-Nya sehingga saya bisa menyelesaikan penyusunan makalah ini yang berjudul "Volume Balok" saya pun menyadari bahwa penyusunan makalah ini masih jauh dari sempurna. Maka dari itu sangat diharapkan kritik dan saran untuk membangun makalah ini.

Ucapan terima kasih juga saya sampaikan kepada pihak-pihak yang telah membantu penyusunan makalah ini. Semoga makalah ini bisa mendatangkan manfaat bagi kita semua, aamiin.

Makassar, 06 Februari 2020

KAMSINAH 


\section{DAFTAR ISI}

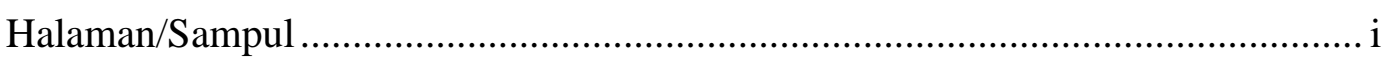

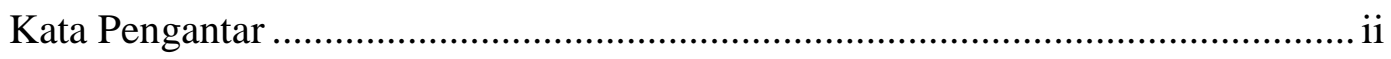

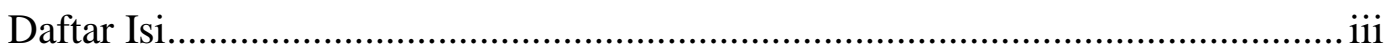

\section{BAB I PENDAHULUAN}
A. Latar Belakang. 1
B. Rumusan Masalah ................................................................................... 1

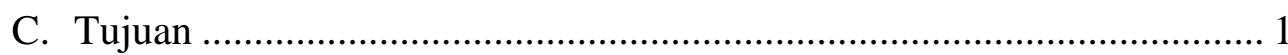

BAB II PEMBAHASAN
A. Volume Kubus 2
B. Model Pembelajaran ........................................................................... 7
C. Metode Pembelajaran ........................................................................... 9

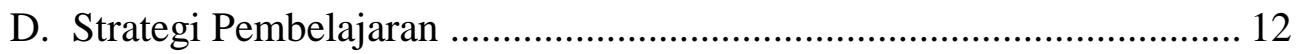

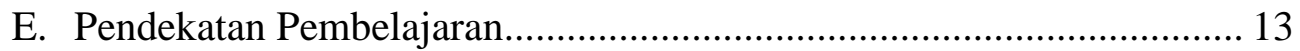

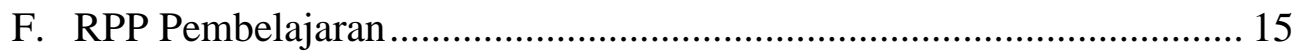

BAB III PENUTUP

A. Kesimpulan

Daftar Pustaka 


\section{BAB I \\ PENDAHULUAN}

\section{A. Latar Belakang}

Kita semua hidup dalam satu ruang. Semua kejadian yang kita saksikan atau kita alami sendiri terjadi dalam ruang itu. Setiap hari kita bergaul dengan benda-benda ruang, seperti lemari, TV, kotak snack, kaleng susu, rumah, tangki air, bak mandi, dan seterusnya. Maka bekal hidup yang kita berikan kepada anak-anak kita melalui pembelajaran di Sekolah Dasar tidak dapat dianggap lengkap apabila tidak meliputi pemahaman ruang. Pemahaman ruang itu dikembangkan melalui pelajaran Bangun Ruang.

Bangun ruang merupakan salah satu komponen matematika yang perlu dipelajari untuk menetapkan konsep keruangan. Maka dalam pelajaran Matematika perlu diberikan topik pembelajaran ini kepada semua peserta didik sejak berada di Sekolah Dasar untuk membekali peserta didik dengan kemampuan berfikir logis, analitis, sistematis, kritis, dan kreatif.

Kompetensi tersebut sangatlah perlu sebagai dasar dari peserta didik untuk mengembangkan kemampuan memperoleh, mengelola, dan memanfaatkan informasi dalam kehidupan sehari-hari. Maka dari itu melalui makalah ini akan dibahas lebih lanjut mengenai bangun ruang lebih tepatnya tentang valome balok.

\section{B. Rumusan Masalah}

1. Apa yang dimaksud dengan balok?

2. Bagaimanakah model pembelajaran materi balok?

3. Bagaimanakah metode pembelajaran materi balok?

4. Bagaimanakah strategi pembelaaran materi balok ?

5. Bagaimanakah pendekatan pembelajaran materi balok ?

\section{Tujuan}

1. Untuk mengetahui balok

2. Untuk mengetahui model pembelajaran materi balok

3. Untuk mengetahui metode pembelajaran materi balok

4. Untuk mengetahui strategi pembelaaran materi balok

5. Untuk mengetahui pendekatan pembelajaran materi balok 
BAB II

\section{PEMBAHASAN}

\section{A. Volume Balok}

\section{Pengertian Balok}

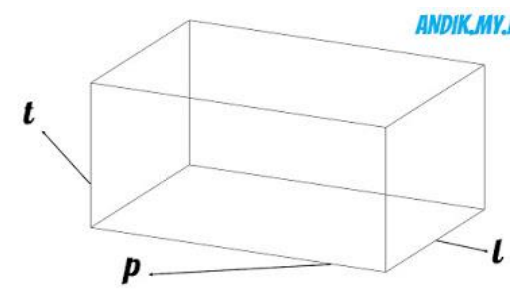

Balok adalah bangun ruang yang memiliki tiga pasang sisi yang ukurannya sama dan saling berhadapan serta memiliki bentuk persegi panjang. Balok adalah bangun ruang tiga dimensi yang dibentuk oleh tiga pasang persegi atau persegi panjang, dengan paling tidak satu pasang di antaranya berukuran berbeda. Balok memiliki 6 sisi, 12 rusuk dan 8 titik sudut. Balok yang dibentuk oleh enam persegi sama dan sebangun disebut sebagai kubus.

Jadi, sebagaimana halnya kubus yang memiliki 6 (enam) sisi, pada balok pun demikian, namun perbedaanya kalau pada kubus keenam sisinya mempunyai bentuk dan ukuran yang sama yaitu berbentuk persegi. Kalau pada balok memiliki tiga pasang sisi yang ukurannya sama besarnya dan berbentuk persegi panjang. Untuk lebih jelansnya memahami pengertian balok ini, silahkan perhatikan gambar balok di bawah ini!

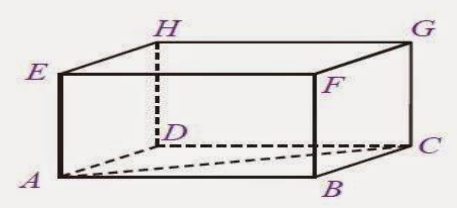

Pada gambar balok ABCD.EFGH di atas dapat diketahui bahwa 3 pasang sisi yang letaknya saling berhadapan dan ukurannya sama besar serta berbentuk persegi panjang adalah sebagai berikut;

a) Sisi $\mathrm{ABCD}=$ sisi $\mathrm{EFGH}$

b) Sisi $\mathrm{ABFE}=$ sisi DCGH

c) Sisi ADHE = sisi BCGF

Sehingga dapat disimpulkan bahwa gambar tersebut diatas adalah terbukti sebagai gambar balok, yaitu memiliki 3 pasang sisi yang ukurannya sama besar 
dan letaknya saling berhadapan serta berbentuk persegi panjang. Walaupun pengertian diatas adalah benar, namun ada beberap kasus bangun ruang yang memiliki 2 pasang sisi yang berntuk persegi panjang dan sepasang sisi yang berbentuk persegi, namun tetap dinamakan sebagai bangun ruang berjenis balok.

Jadi dapat disimpulkan bahwa balok adalah bangun ruang yang memiliki tiga pasang sisi yang letaknya saling berhadapan dan ukuran masing-masing pasangannya sama besar serta berbentuk persegi panjang atau minimal dua sisi yang berpasangan berbentuk persegi panjang.

\section{Sifat- Sifat Balok}

a. Sisi-sisi balok berbentuk persegipanjang.

Coba kamu perhatikan sisi ABCD, EFGH, ABFE, dan seterusnya. Sisi-sisi tersebut memiliki bentuk persegi panjang. Dalam balok, minimal memiliki dua pasang sisi yang berbentuk persegi panjang.

b. Rusuk-rusuk yang sejajar memiliki ukuran sama panjang.

Perhatikan rusuk-rusuk balok pada gambar di atas. Rusuk-rusuk yang sejajar seperti $\mathrm{AB}, \mathrm{CD}, \mathrm{EF}$, dan $\mathrm{GH}$ memiliki ukuran yang sama panjang begitu pula dengan rusuk $\mathrm{AE}, \mathrm{BF}, \mathrm{CG}$, dan $\mathrm{DH}$ memiliki ukuran yang sama panjang.

c. Setiap diagonal bidang pada sisi yang berhadapan memiliki ukuran sama panjang.

Dari gambar terlihat bahwa panjang diagonal bidang pada sisi yang berhadapan, yaitu ABCD dengan EFGH, ABFE dengan DCGH, dan BCFG dengan ADHE memiliki ukuran yang sama panjang.

d. Setiap diagonal ruang pada balok memiliki ukuran sama panjang.

Diagonal ruang pada balok ABCD.EFGH, yaitu AG, EC, DF, dan HB memiliki panjang yang sama.

e. Setiap bidang diagonal pada balok memiliki bentuk persegi panjang.

\section{Volume Balok}

Untuk menghitung volume atau isi sebuah balok, maka harus diketahui dimensi panjang, lebar, dan tinggi kotak tersebut. Rumus untuk menghitung volume kotak adalah sbb: 


$$
\text { volume }=\text { panjang } \mathrm{x} \text { lebar } \mathrm{x} \text { tinggi }
$$

Rumus ini seringkali ditulis secara lebih disingkat sebagai V $=\mathrm{P}$ x L x T. Perlu diperhatikan bahwa dalam menghitung volume sebuah kotak menggunakan rumus di atas, dimensi panjang, lebar dan tingginya harus dalam satuan yang sama. Satuan volume adalah satuan panjang kubik misalnya millimeter kubik (mm3), centimeter kubik (cm3), meter kubik (m3), dan lain sebagainya.

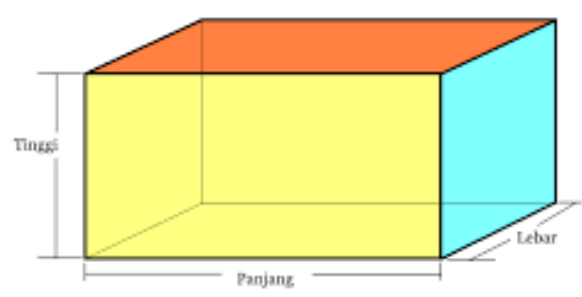

Volume Balok $V=p x l x t$

\section{Contoh soal volume balok}

1) Diketahui ukuran pada bangun ruang balok seperti digambar. Maka tentukan berapa volume balok yang ada pada gambar?

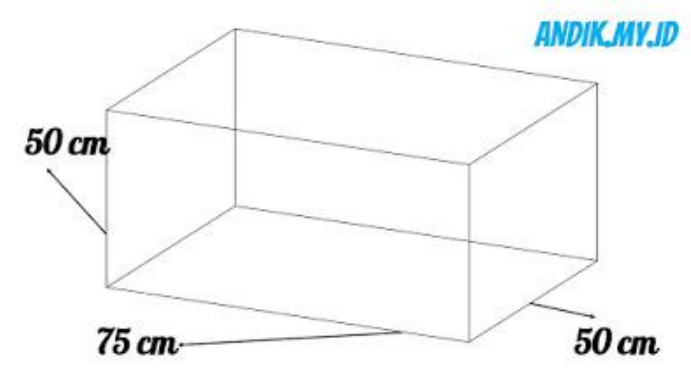

Diketahui :

Panjang $(p)=75 \mathrm{~cm}$

Lebar (l) $=50 \mathrm{~cm}$

Tinggi $(\mathrm{t})=50 \mathrm{~cm}$

Jawab :

Volume balok $=\mathrm{p} \times 1 \times \mathrm{t}$

$=75 \mathrm{~cm} \times 50 \mathrm{~cm} \times 50 \mathrm{~cm}$

$=187.500 \mathrm{~cm}^{3}$

$=187,5 \mathrm{dm}^{3-}$ 
$=187,5$ liter

Perlu diketahu bahwa satuan volume adalah kubik. Seperti pada soal diatas, maka luas balok adalah $187.500 \mathrm{~cm}^{3}$, satuan $\mathrm{cm}^{3}$ dibaca dengan centi meter kubik. Agar lebih sederhana, saya akan menggunakan ukuran liter atau $\mathrm{dm}^{3}$. Bahwa $1000 \mathrm{~cm}^{3}$ sama dengan $1 \mathrm{dm}^{3}$, sehingga jika $187.500 \mathrm{~cm}^{3}$ maka artinya sama dengan $187,5 \mathrm{dm}^{3}$. Perlu diketahui lagi, bahwa ukuran $\mathrm{dm}^{3}$ itu ukurannya sama dengan liter. Sehingga jika $187,5 \mathrm{dm}^{3}$ itu artinya sama denan 187,5 liter.

2) Sebuah balok mempunyai ukuran panjang, lebar, dan tinggi masing-masing $9 \mathrm{~cm}, 8 \mathrm{~cm}$, dan $10 \mathrm{~cm}$. Berapa volume balok tersebut? (Petunjuk: volume kotak $=$ panjang $\mathrm{x}$ lebar $\mathrm{x}$ tinggi).

Jawab:

Volume balok $=9 \mathrm{~cm} \times 8 \mathrm{~cm} \times 10 \mathrm{~cm}=720 \mathrm{~cm}^{3}$.

3) Diketahui suatu balok memiliki panjang $10 \mathrm{~m}$, lebar $2 \mathrm{~m}$, dan tingginya $100 \mathrm{~cm}$. Hitung volume balok tersebut.

Jawab

Cara pengerjaan untuk menghitung volume balok tersebut sebenarnya sama seperti contoh soal sebelumnya. Akan tetapi, perlu diperhatikan bahwa satuan dalam ukuran sisi balok tersebut belum sama.

Oleh karena itu, kita harus menyamakannya dulu.

Panjang, $\mathrm{p}=10 \mathrm{~m}$

Lebar, $1=2 \mathrm{~m}$

Tinggi, $\mathrm{t}=100 \mathrm{~cm}=1 \mathrm{~m}$

Selanjutnya tinggal menghitung dengan rumus balok:

$$
\begin{aligned}
& \mathrm{V}=\mathrm{p} \times 1 \times \mathrm{t} \\
& \mathrm{V}=10 \times 2 \times 1 \\
& \mathrm{~V}=20 \mathrm{~m}^{3}
\end{aligned}
$$


4) Diketahui sebuah balok dengan ukuran sebagai berikut!

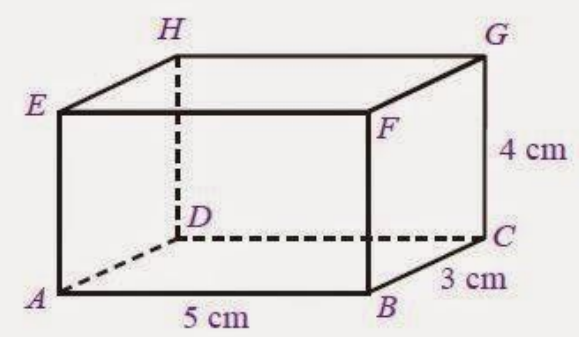

a. Tentukan luas permukaan balok!

b. Tentukan volume balok!

\section{Jawab:}

Diketahui $\mathrm{p}=5 \mathrm{~cm}, 1=3 \mathrm{~cm}$, dan $\mathrm{t}=4 \mathrm{~cm}$.

a. Luas permukaan $=2(\mathrm{pl}+\mathrm{lt}+\mathrm{pt})$

$$
\begin{aligned}
& =2(5 \times 3+3 \times 4+5 \times 4) \\
& =2(15+12+20) \\
& =2(47) \\
& =94
\end{aligned}
$$

Jadi, luas permukaan balok tersebut adalah $94 \mathrm{~cm} 2$.

b. Volume balok $=\mathrm{p} \times 1 \times \mathrm{t}$

$$
\begin{aligned}
& =5 \times 3 \times 4 \\
& =60 \mathrm{~cm}^{3}
\end{aligned}
$$

Jadi, volume balok tersebut adalah $60 \mathrm{~cm} 3$.

5) Hitunglah volume balok yang mempunyai panjang $10 \mathrm{~cm}$, lebar $8 \mathrm{~cm}$ dan tinggi $5 \mathrm{~cm}$

Penyelesaian:

Diketahui:

$\mathrm{P}=10 \mathrm{~cm}$

$\mathrm{L}=8 \mathrm{~cm}$

$\mathrm{t}=5 \mathrm{~cm}$

jawab

$\mathrm{V}=\mathrm{PxLxt}$

$\mathrm{V}=10 \mathrm{~cm} \times 8 \mathrm{~cm} \times 5 \mathrm{~cm}$

$\mathrm{V}=400 \mathrm{~cm}^{3}$ 


\section{B. Model Pembelajaran}

Model pembelajaran adalah kerangka kerja yang memberikan gambaran sistematis untuk melaksanakan pembelajaran agar membantu belajar siswa dalam tujuan tertentu yang ingin dicapai. Artinya, model pembelajaran merupakan gambaran umum namun tetap mengerucut pada tujuan khusus.

Model pembelajaran yang sesuai dengan materi volume balok adalah model pembelajaran numbered heads together. Model Pembelajaran NHT (Numbered Head Together) merupakan salah satu yang termasuk atau tergolong dalam jenis model pembelajaran kooperatif. namun prosedur dan pelaksanaannya memiliki spesifik tersendiri yang berbeda dengan model pembelajaran kooperatif yang lainnya. Model pembelajaran NHT (Numbered Head Together) adalah jenis pembelajaran yang tergolong ke dalam model kooperatif yang tujuannya dirancang untuk mempengaruhi pola interaksi siswa dan sebagai salah satu alternatif terhadap sturktur kelas tradisional. Model pembelajaran NHT (Number Head Together) pertama kali dikembangkan oleh Spenser Kagen (1993) untuk melibatkan banyak siswa dalam mengikuti, menelaah, dan dapat menguasai materi dalam suatu pelajaran. Sehingga siswa dapat mengecek pemahaman mereka terhadap isi pelajaran yang sedang dipelajari tersebut.

Adapun langkah-langkah model pembelajaran numbered heads together yaitu: Langkah-langkah dikembangkan oleh Ibrahim (2000: 29) menjadi enam langkah sebagai berikut :

Langkah 1. Persiapan

Dalam tahap ini guru mempersiapkan rancangan pelajaran dengan membuat Skenario Pembelajaran (SP), Lembar Kerja Siswa (LKS) yang sesuai dengan model pembelajaran kooperatif tipe NHT.

\section{Langkah 2. Pembentukan kelompok}

Dalam pembentukan kelompok disesuaikan dengan model pembelajaran kooperatif tipe NHT. Guru membagi para siswa menjadi beberapa kelompok yang beranggotakan 3-5 orang siswa. Guru memberi nomor kepada setiap siswa dalam kelompok dan nama kelompok yang berbeda. Kelompok yang dibentuk merupakan percampuran yang ditinjau dari latar belakang sosial, ras, 
suku, jenis kelamin dan kemampuan belajar. Selain itu, dalam pembentukan kelompok digunakan nilai tes awal (pre-test) sebagai dasar dalam menentukan masing-masing kelompok.

\section{Langkah 3. Tiap kelompok harus memiliki buku paket atau buku panduan}

Dalam pembentukan kelompok, tiap kelompok harus memiliki buku paket atau buku panduan agar memudahkan siswa dalam menyelesaikan LKS atau masalah yang diberikan oleh guru.

Langkah 4. Diskusi masalah

Dalam kerja kelompok, guru membagikan LKS kepada setiap siswa sebagai bahan yang akan dipelajari. Dalam kerja kelompok setiap siswa berpikir bersama untuk menggambarkan dan meyakinkan bahwa tiap orang mengetahui jawaban dari pertanyaan yang telah ada dalam LKS atau pertanyaan yang telah diberikan oleh guru. Pertanyaan dapat bervariasi, dari yang bersifat spesifik sampai yang bersifat umum.

Langkah 5. Memanggil nomor anggota atau pemberian jawaban

Dalam tahap ini, guru menyebut satu nomor dan para siswa dari tiap kelompok dengan nomor yang sama mengangkat tangan dan menyiapkan jawaban kepada siswa di kelas.

Langkah 6. Memberi kesimpulan

Guru bersama siswa menyimpulkan jawaban akhir dari semua pertanyaan yang berhubungan dengan materi yang disajikan.

Cara Penggunaan Model Numbered Heads Together dengan Materi Volume Balok

1. Pertama, guru harus menyiapkan materi terlebih dahulu yaitu materi tentang volume balok, LKS dan lain-lain untuk permbelajaran yang akan dilaksanakan

2. Kedua, pembagian kelompok dilakukan. Pembagian kelompok ini disesuaikan dengan jumlah siswa-siswi di kelas dan juga memberikan penjelasan atau petunjuk bagi semua kelompok dalam mengikuti proses pembelajaran 
3. Ketiga, guru membagikan/menjelaskan materi mengenai volume balok pada semua kelompok dan juga LKS yang akan dikerjakan.

4. Dalam kerja kelompok setiap siswa berpikir bersama untuk menggambarkan dan meyakinkan bahwa tiap orang mengetahui jawaban dari pertanyaan yang telah ada dalam LKS valume balok atau pertanyaan yang telah diberikan oleh guru. Pertanyaan dapat bervariasi, dari yang bersifat spesifik sampai yang bersifat umum.

5. Pada kegiatan ini guru menyebut satu nomor dan para siswa dari tiap kelompok dengan nomor yang sama mengangkat tangan dan menyiapkan jawaban kepada siswa di kelas. Misalnya guru menanyakan terkait cara pengerjaan dari soal yang terdapat dalam LKS yaitu menghitung volume dari balok, sifat-sifat balok dan lain-lain

6. Setiap perwakilan kelompok yang berhasil menjawab mendapat poin sedangkan yang belum bisa menjawab bisa dilempar ke kelompok lain.

7. Setelah kegiatan selesai guru pun memberikan kesimpulan dan review terkait materi volume balok yang telah dipelajari.

\section{Metode Pembelajaran}

Metode pembelajaran adalah cara kerja sistematis yang memudahkan pelaksanaan pembelajaran berupa implementasi spesifik langkah-langkah konkret agar terjadi proses pembelajaran yang efektif mencapai suatu tujuan tertentu seperti perubahan positif pada peserta didik.

Metode yang sesuai dengan materi serta model pembelajaran matematika (volume balok) adalah metode diskusi ialah metode menyajikan pelajaran dimana siswa dihadapkan kepada suatu masalah untuk dipecahkan bersama dalam bentuk kelompok dan juga dapat menyimpulkan hasil diskusinya. Dalam penelitian ini siswa diminta untuk membentuk kelompok dan duduk besama dalam kelompok masing-masing,untuk mendengarkan penjelasan materi fotosintesis yang disampaikan oleh guru. Siswa mendengarkan penjelasan dengan baikagar mereka dapat menjawab pertanyaan dari guru ketika ditanya. Setelah materi selesai, guru memberikan kesempatan kepada peserta didik untuk menanyakan tentang materi 
pelajaran yang belum dipahami, dan memberikan jawaban yang memuaskan atas pertanyaan siswa.

Kemudian siswa masuk kedalam kelompok-kelompok belajar sesuai dengan metode diskusi yang digunakan, sementara itu guru memberikan lembar latihan untuk didiskusikan secara berkelompok. Guru membimbing siswa dalam kegiatan diskusi kelompok, apabila sudah selesai mengejakan tugas kelompok, satu orang siswa diminta untuk mempersentasikan hasil diskusi nya mewakili masing-masing kelompok. Guru biasanya membimbing peserta didik untuk merangkum materi pelajaran agar dapat lebih mudah dipahami oleh siswa sehingga dapat di ingat dengan baik.

Agar penggunan diskusi berhasil dengan efektif, maka perlu dilakukan langkahlangkah sebagai berikut:

a. Langkah persiapan

Hal-hal yang harus diperhatikan dalam persiapan diskusi diantaranya:

1. Merumuskan tujuan yang ingin dicapai, baik tujuan yang bersifat umum maupun tujuan khusus.

2. Menentukan jenis diskusi yang dapat dilaksanakan sesuai dengan tujuan yang ingin dicapai.

3. Menetapkan masalah yang akan dibahas.

4. Mempersiapkan segala sesuatu yang berhubungan dengan teknis pelaksanaan diskusi, misalnya ruang kelas dengan segala fasilitasnya, petugas-petugas diskusi seperti moderator, notulis, dan tim perumus manakala diperlukan.

b. Pelaksanaan diskusi

Beberapa hal yang perlu diperhatikan dalam melaksanakan diskusi adalah:

1. Memeriksa segala persiapan yang dianggap dapat memengaruhi kelancaran diskusi.

2. Memberikan pengarahan sebelum dilaksanakan diskusi, misalnya menyajikan tujuan yang ingin dicapai serta aturan-aturan diskusi sesuai dengan jenis diskusi yang akan dilaksanakan. 
3. Melaksanakan diskusi sesuai dengan aturan main yang telah ditetapkan. Dalam pelaksanaan diskusi hendaklah memerhatikan suasana atau iklim belajar yang menyenangkan, misalnya tidak tegang, tidak saling menyudutkan, dan harus saling menghargai pendapat orang lain.

4. Memberikan kesempatan yang sama kepada setiap peserta diskusi untuk mengeluarkan gagasan dan ide-idenya.

5. Mengendalikan pembicaraan kepada pokok persoalan yang sedang dibahas. Hal ini sangat penting, sebab tanpa pengendalian biasanya arah pembahasan menjadi melebar dan tidak fokus.

c. Menutup diskusi

Akhir dari proses pembelajaran dengan menggunakan diskusi hendaklah dilakuan hal-hal sebagai berikut:

1. Membuat pokok-pokok pembahasan sebagai kesimpulan sesuai dengan hasil diskusi.

2. Me-review jalannya diskusi dengan meminta pendapat dari seluruh peserta sebagai umpan balik untuk perbaikan selanjutnya.

Cara Penggunaan Metode Diskusi dengan Materi Volume Balok

a. Langkah persiapan

Hal-hal yang harus diperhatikan dalam persiapan diskusi diantaranya:

1. Merumuskan tujuan yang ingin dicapai dari materi volume balok baik tujuan yang bersifat umum maupun tujuan khusus.

2. Menentukan jenis diskusi yang dapat dilaksanakan sesuai dengan tujuan yang ingin dicapai.

3. Mempersiapkan segala sesuatu yang berhubungan dengan teknis pelaksanaan diskusi seperti materi, LKS dan lain-lain.

4. Menetapkan atau memberikan tugas yang akan dibahas/didiskusikan.

b. Pelaksanaan diskusi

Beberapa hal yang perlu diperhatikan dalam melaksanakan diskusi adalah: 
1. Memeriksa segala persiapan yang dianggap dapat memengaruhi kelancaran diskusi.

2. Memberikan pengarahan terlebih dahulu sebelum dilaksanakan diskusi.

3. Dalam pelaksanaan diskusi hendaklah memerhatikan suasana atau iklim belajar yang menyenangkan, misalnya tidak tegang, tidak saling menyudutkan, dan harus saling menghargai pendapat orang lain.

4. Memberikan kesempatan yang sama kepada setiap peserta diskusi untuk mengeluarkan gagasan dan ide-idenya, terkait materi yang didiskusikann

5. Mengendalikan pembicaraan kepada pokok persoalan yang sedang dibahas. Hal ini sangat penting, sebab tanpa pengendalian biasanya arah pembahasan menjadi melebar dan tidak fokus.

c. Menutup diskusi

Akhir dari proses pembelajaran dengan menggunakan diskusi hendaklah dilakuan hal-hal sebagai berikut:

1. Membuat pokok-pokok pembahasan sebagai kesimpulan sesuai dengan hasil diskusi materi volume balok .

2. Me-review jalannya diskusi dengan meminta pendapat dari seluruh peserta sebagai umpan balik untuk perbaikan selanjutnya.

\section{Strategi Pembelajaran}

Strategi pembelajaran yaitu suatu rencana rangkaian kegiatan yang pada pemakaian metode dan penggunaan akan semua sumber daya atau kekuatan demi adanya pembelajaran yang disusun untuk meraih tujuan tertentu.

Strategi pembelajaran yang saya pilih yaitu Strategi pembelajaran kooperatif atau SPK, strategi pembelajaran ini yaitu serangkaian kegiatan belajar yang dilakukan siswa dalam kelompok tertentu agar bisa mencapai tujuan pembelajaran yang sudah dirumuskan. Strategi pembelajaran kooperatif menggunakan sistem pengelompokan maupun tim kecil antara 4 hingga 6 orang yang yang sama-sama memiliki latar belakang dalam kemampuan akademik, ras maupun jenis kelamin. 
Sedangkan untuk sistem penilaiannya juga dilakukan terhadap kelompok. Sehingga masing-masing kelompok memiliki penghargaan atau reward apabila kelompok tersebut memiliki atau menunjukkan prestasi sesuai yang telah di persyaratan. Dengan adanya reward atau penghargaan maka dapat menambah motivasi para siswa untuk lebih giat dalam belajar.

\section{Cara Penggunaan Strategi Pembelajaran Kooperatif atau SPK Materi}

\section{Volume Balok}

1. Menyampaikan tujuan dan memotivasi siswa. Guru menyampaikan tujuan pembelajaran dan mengkomunikasikan kompetensi dasar yang akan dicapai serta memotivasi siswa.

2. Menyajikan informasi. Guru menyajikan informasi kepada siswa, informasi ini isa berupa materi atau arahan terkait pembelajaran.

3. Mengorganisasikan siswa ke dalam kelompok-kelompok belajar. Guru menginformasikan pengelompokan siswa.

4. Membimbing kelompok belajar. Guru memotivasi serta memfasilitasi kerja siswa dalam kelompok kelompok belajar.

5. Evaluasi. Guru mengevaluasi hasil belajar tentang materi volume balokpembelajaran yang telah dilaksanakan.

6. Memberikan penghargaan. Guru memberi penghargaan hasil belajar individual dan kelompok.

\section{E. Pendekatan Pembelajaran}

Pendekatan pembelajaran dapat diartikan sebagai titik tolak atau sudut pandang kita terhadap proses pembelajaran, yang merujuk pada pandangan tentang terjadinya suatu proses yang sifatnya masih sangat umum, di dalamnya mewadahi, menginsiprasi, menguatkan, dan melatari metode pembelajaran dengan cakupan teoretis tertentu.

Pendekatan yang saya pilih, yaitu: Pendekatan Student Centered pendekatan student centered mendorong siswa untuk mengerjakan sesuatu sebagai pengalaman praktik dan membangun makna atas pengalaman yang diperolehnya. Pusat pembelajaran diserahkan langsung ke peserta didik dengan supervisi dari Guru. 
Pendekatan pembelajaran yang berpusat pada siswa menurunkan strategi pembelajaran seperti discovery learning dan inquiry (penyingkapan atau penyelidikan).

Penerapan SCL dalam pembelajaran :

1. Kadar SCL dilihat dari proses perencanaan yaitu :

Adanya keterlibatan siswa dalam :

- Perumusan tujuan pembelajaran yang akan dipelajari

- Menyusun rancangan pembelajaran

- Menentukan dan memilih sumber belajar yang akan digunakan

2. Kadar SCL dilihat dari proses pembelajaran yaitu :

- Adanya keterlibatan siswa secara fisik, mental, emosional dan spiritual dalam proses pembelajaran,

- Siswa belajar secara langsung di kelas,

- Adanya keinginan siswa untuk terciptanya iklim belajar yang kondusif,

- Prakarsa siswa dalam memecahkan masalah,

- Terjadi interaksi multi arah.

3. Kadar SCL dilihat dari kegiatan evaluasi yaitu :

- Adanya self assessment,

- Kemandirian siswa dalam kegiatan evaluasi,

- Kemauan siswa dalam menyusun laporan kegiatan belajar. 


\title{
RENCANA PELAKSANAAN PEMBELAJARAN
}

\section{MATEMATIKA}

\author{
Satuan Pendidikan : SDN 8 Batu Malang \\ Mata Pelajaran : Matematika \\ Kelas /Semester : : V / 1 \\ Materi Pokok : Volume Bangun Ruang \\ Alokasi Waktu : 3 JP $(3 \times 35$ menit $)$
}

A. KOMPETENSI DASAR DAN INDIKATOR

\begin{tabular}{|c|c|}
\hline Kompetensi Dasar (KD) & Indikator Pencapaian Kompetensi (IPK) \\
\hline $\begin{array}{l}\text { 3.5 Menjelaskan, dan } \\
\text { menentukan volume bangun } \\
\text { ruang dengan menggunakan } \\
\text { satuan volume (seperti kubus } \\
\text { satuan) serta } \\
\text { hubungan pangkat tiga } \\
\text { dengan akar pangkat tiga. }\end{array}$ & $\begin{array}{ll}\text { 3.5.1 } & \text { Memahami satuan volume } \\
\text { 3.5.2 } & \text { Menganalisis unsur dan volume kubus } \\
\text { 3.5.3 } & \text { Menganalisis unsur dan volume balok } \\
\text { 3.5.4 } & \text { Memahami cara menentukan volume } \\
& \text { kubus dan balok }\end{array}$ \\
\hline $\begin{array}{l}\text { 4.5 Menyelesaikan masalah yang } \\
\text { berkaitan dengan volume } \\
\text { bangun ruang dengan } \\
\text { menggunakan satuan volume } \\
\text { (seperti kubus } \\
\text { satuan) melibatkan pangkat } \\
\text { tiga dan akar pangkat tiga. }\end{array}$ & 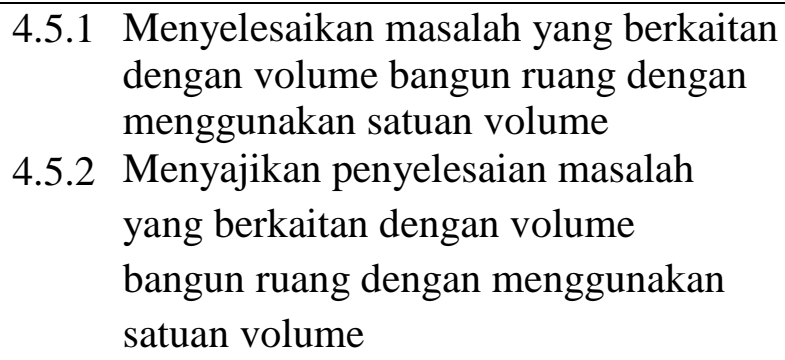 \\
\hline
\end{tabular}

\section{B. TUJUAN PEMBELAJARAN}

1. Dengan mengamati gambar melalui media daring classroom, siswa dapat Memahami satuan volume dengan baik.

2. Dengan mengamati gambar melalui media daring zoom, siswa dapat menganalisis unsur dan volume kubus dengan benar.

3. Dengan mengamati gambar melalui media daring zoom, siswa dapat menganalisis unsur dan volume balok dengan benar

4. Dengan mengamati video melalui media daring zoom, siswa dapat memahami cara menentukan volume kubus dan balok dengan tepat.

5. Setelah mengamati video melalui media daring zoom menyelesaikan masalah yang berkaitan dengan volume bangun ruang dengan menggunakan satuan volume

6. Setelah mengamati video melalui media daring zoom menyajikan penyelesaian masalah yang berkaitan dengan volume bangun ruang dengan menggunakan satuan volume.

\section{MATERI PEMBELAJARAN}

\section{Fakta:}

Contoh-contoh gambar balok dan kubus 


\section{Konsep}

- Kubus adalah balok atau prismasiku-siku khusus.

- Balok disebut prisma siku-siku. Balok mempunyai 6 sisi, masingmasing berbentuk persegi panjang.

\section{Prinsip}

Menyelesaikan masalah yang berkaitan dengan volume bangun ruang dengan menggunakan satuan volume (seperti kubus satuan)

\section{Prosedur}

- Menyelesaikan masalah yang berkaitan dengan volume bangun ruang dengan menggunakan satuan volume

- Menyajikan penyelesaian masalah yang berkaitan dengan volume bangun ruang dengan menggunakan satuan volume

\section{METODE PEMBELAJARAN}

1. Pendekatan

: Student Centered

2. Model Pembelajaran

3. Metode

: Numbered Heads Together

4. Strategi

: Metode Diskusi

: Strategi pembelajaran kooperatif

\section{E. MEDIA PEMBELAJARAN}

1. Video

2. Gambar

3. Benda berbentuk balok

\section{F. SUMBER BELAJAR}

1. Buku Siswa Matematika Kelas V Revisi 2017

2. Buku Petunjuk Guru Matematika Kelas V Revisi 2017

3. Modul/bahan ajar,

\section{G. Kegiatan Pembelajaran}

\begin{tabular}{|c|c|c|}
\hline Kegiatan & Deskripsi Kegiatan & $\begin{array}{l}\text { Alokasi } \\
\text { waktu }\end{array}$ \\
\hline Pendahuluan & $\begin{array}{l}\text { Guru : } \\
\text { Orientasi } \\
\text { 1. Guru membuka pembelajaran dengan salam } \\
\text { pembuka dan berdoa untuk memulai pembelajaran } \\
\text { 2. Memeriksa kehadiran peserta didik } \\
\text { Apersepsi } \\
\text { 3. Mengajukan pertanyaan yang ada keterkaitannya } \\
\text { dengan pelajaran yang akan dilakukan } \\
\text { Motivasi } \\
\text { 4. Memberikan gambaran tentang manfaat } \\
\text { mempelajari pelajaran yang akan dipelajari } \\
\text { Menyampaikan tujuan pembelajaran pada } \\
\text { pertemuan yang berlangsung. }\end{array}$ & $\begin{array}{l}15 \\
\text { menit }\end{array}$ \\
\hline
\end{tabular}




\begin{tabular}{|c|c|c|}
\hline Inti & $\begin{array}{l}\text { 3. Guru melakukan pembagian kelompok. } \\
\text { Pembagian kelompok ini } 4 \text { sampai } 6 \text { orang } \\
\text { 4. Setelah itu memberikan penjelasan atau petunjuk } \\
\text { bagi semua kelompok dalam mengikuti proses } \\
\text { pembelajaran } \\
\text { Guru membagikan/menjelaskan materi mengenai } \\
\text { volume balok pada semua kelompok dan juga } \\
\text { LKS yang akan dikerjakan. } \\
\text { Dalam kerja kelompok setiap siswa berpikir } \\
\text { bersama untuk menggambarkan dan meyakinkan } \\
\text { bahwa tiap orang mengetahui jawaban dari } \\
\text { pertanyaan yang telah ada dalam LKS valume } \\
\text { balok atau pertanyaan yang telah diberikan oleh } \\
\text { guru. Pertanyaan dapat bervariasi, dari yang } \\
\text { bersifat spesifik sampai yang bersifat umum. } \\
\text { Pada kegiatan ini guru menyebut satu nomor dan } \\
\text { para siswa dari tiap kelompok dengan nomor yang } \\
\text { sama mengangkat tangan dan menyiapkan } \\
\text { jawaban kepada siswa di kelas. Misalnya guru } \\
\text { menyebut nomor } 3 \text { maka masing-masing anggota } \\
\text { kelompok yang mendapat nomor urut } 3 \text { harus } \\
\text { menjawab soal yang diberikan oleh guru } \\
\text { contohnya menanyakan terkait cara pengerjaan } \\
\text { dari soal yang terdapat dalam LKS yaitu } \\
\text { menghitung volume dari balok, sifat-sifat balok } \\
\text { dan lain-lain. }\end{array}$ & $\begin{array}{l}75 \\
\text { menit }\end{array}$ \\
\hline
\end{tabular}




\begin{tabular}{|c|c|}
\hline & $\begin{array}{l}\text { 8. Setiap perwakilan kelompok yang berhasil } \\
\text { menjawab mendapat poin sedangkan yang belum } \\
\text { bisa menjawab bisa dilempar ke kelompok lain. }\end{array}$ \\
\hline Penutup & $\begin{array}{l}\text { 9. Guru bersama siswa membuat kesimpulan : } \\
\text { "Dari kegia tan hari ini apa yang dapat kalian } \\
\text { pelajari? } \\
\text { 10. Guru mengajak murid untuk refleksi: } \\
\text { "Bagaimana pembelajaran hari ini?" } \\
\text { 11. Pembelajaran di tutup dengan doa: "Semoga } \\
\text { kegiatan hari ini bermanfaat bagi kita dan kita } \\
\text { diberikan kesehatan } \\
\text { sehingga besok bisa belajar kembali" }\end{array}$ \\
\hline
\end{tabular}

\section{F. PENILAIAN, PEMBELAJARAN REMEDIAL DAN PENGAYAAN}

\section{Teknik Penilaian}

a. Penilaian Kompetensi Pengetahuan

a) Uraian/esai

\section{b. Penilaian Kompetensi Keterampilan}

1) Proyek, pengamatan, wawancara'

a) Mempelajari buku teks dan sumber lain tentang materi pokok

b) Menyimak tayangan/demo tentang materi pokok

c) Menyelesaikan tugas yang berkaitan dengan pengamatan dan eksplorasi

2) Portofolio / unjuk kerja

a) Laporan tertulis individu/ kelompok

3) Produk

\section{Instrumen Penilaian: Terlampir}

\section{Penilaian Sikap}

\begin{tabular}{|c|c|c|c|c|c|c|c|c|c|c|c|c|c|c|c|c|c|}
\hline \multirow{3}{*}{ No. } & \multirow{3}{*}{$\begin{array}{l}\text { Nama peserta } \\
\text { didik }\end{array}$} & \multicolumn{16}{|c|}{ Aktifitas } \\
\hline & & \multicolumn{4}{|c|}{ Kerja sama } & \multicolumn{4}{|c|}{ Keaktifan } & \multicolumn{4}{|c|}{ Partisipasi } & \multicolumn{4}{|c|}{ Inisiatif } \\
\hline & & 1 & 2 & 3 & 4 & 1 & 2 & 3 & 4 & 1 & 2 & 3 & 4 & 1 & 2 & 3 & 4 \\
\hline 1 & & & & & & & & & & & & & & & & & \\
\hline 2 & & & & & & & & & & & & & & & & & \\
\hline
\end{tabular}

Rubrik penilaian:

1. Apabila peserta didik belum memperlihatkan perilaku yang dinyatakan dalam indikator.

2. Apabila sudah memperlihatkan perilaku tetapi belum konsisten yang dinyatakan dalam indikator. 
3. Apabila sudah memperlihatkan perilaku dan sudah konsisten yangdinyatakan dalam indikator.

4. Apabilasudahmemperlihatkanperilakukebiasaanyangdinyatakandalam indikator.

\section{Catatan :}

Penguasaan nilai disesuaikan dengan karakter yang diinginkan.

Rentang Skor = Skor Maksimal - Skor Minimal

\begin{tabular}{|r|r|}
\hline MK= & $14-16$ \\
\hline MB= & $11-13$ \\
\hline MT $=$ & $8-10$ \\
\hline BT $=$ & $4-7$ \\
\hline
\end{tabular}

Keterangan:

\begin{tabular}{|l|l|}
\hline BT & $\begin{array}{l}\text { BelumTerlihat(apabilapesertadidikbelummemperlihatkantanda- } \\
\text { tanda awal perilaku yang dinyatakan dalam indikator). }\end{array}$ \\
\hline MT & MulaiTerlihat(apabilapesertadidiksudahmulaimemperlihatkan \\
\hline
\end{tabular}

\begin{tabular}{|l|l|}
\hline & $\begin{array}{l}\text { adanyatanda-tandaawalperilakuyangdinyatakandalamindikator } \\
\text { tetapi belum konsisten). }\end{array}$ \\
\hline MB & $\begin{array}{l}\text { MulaiBerkembang(apabilapesertadidiksudahmemperlihatkan } \\
\text { berbagaitanda perilaku yang dinyatakan dalam indikator dan } \\
\text { mulai }\end{array}$ \\
\hline MK & $\begin{array}{l}\text { Mulaimembudaya/terbiasa(apabilapesertadidikterus-menerus } \\
\text { memperlihatkan perilaku yang dinyatakan dalam indikator } \\
\text { secara konsisten). }\end{array}$ \\
\hline
\end{tabular}

Nama sekolah

Jurnal (buku catatan harian tentang peserta didik oleh guru)

Mata pelajaran

Kelas

\begin{tabular}{|c|c|c|c|}
\hline No. & Hari/Tanggal & Nama Peserta didik & Kejadian \\
\hline 1. & & & \\
\hline 2. & & & \\
\hline 3. & & & \\
\hline dst. & & & \\
\hline
\end{tabular}


Kolom kejadian diisi dengan kejadian positif maupun negatif.Catatan dalam lembaran buku tersebut, selain bermanfaat untuk merekam dan menilai perilaku peserta didik, sangat bermanfaat pula untuk menilai sikap peserta didik serta dapat menjadi bahan dalam penilaian perkembangan peserta didik secara keseluruhan. Selain itu, dalam observasi perilaku, dapat juga digunakandaftarcek yang memuat perilaku-perilaku tertentu yang diharapkan muncul dari peserta didik pada umumnya atau dalam keadaan tertentu.

\section{Kisi-Kisi TesTertulis /Uraian/Essai}

\begin{tabular}{|c|c|c|c|c|c|}
\hline No & KompetensiDasar & Materi & IndikatorSoal & $\begin{array}{c}\text { Bentuk } \\
\text { Soal }\end{array}$ & $\begin{array}{l}\text { Jumla } \\
\text { hSoal }\end{array}$ \\
\hline 1 & $\begin{array}{l}\text { 3.5 Menjelaskan dan } \\
\text { menentukan } \\
\text { volume bangun } \\
\text { ruang dengan } \\
\text { menggunakan } \\
\text { satuan volume } \\
\text { (seperti kubus } \\
\text { satuan) }\end{array}$ & $\begin{array}{l}\text { - Volume } \\
\text { bangun } \\
\text { ruang }\end{array}$ & $\begin{array}{l}\text { - Memahami } \\
\text { satuan } \\
\text { volume } \\
\text { - Menganalisis } \\
\text { unsur dan } \\
\text { volume kubus } \\
\text { - Menganalisis } \\
\text { unsur dan } \\
\text { volume balok } \\
\text { - Memahami } \\
\text { cara } \\
\text { menentukan } \\
\text { volume kubus } \\
\text { dan balok }\end{array}$ & Uraian & \\
\hline
\end{tabular}

\section{Contoh butir soal:}

1. Akuarium memiliki ukuran panjang $75 \mathrm{~cm}$, lebar $35 \mathrm{~cm}$ dan tinggi $50 \mathrm{~cm}$. Telah terisi air setinggi $35 \mathrm{~cm}$. Berapa liter air yang ada di dalamakuarium?

2. Volume balok $22.500 \mathrm{~cm}^{3}$. Jika panjang $45 \mathrm{~cm}$ dan lebarnya $20 \mathrm{~cm}$. Berapacm tinggi balok?

Pedoman Penskoran Soal Uraian

\begin{tabular}{|c|l|c|}
\hline No. Soal & \multicolumn{1}{|c|}{ Rubrik } & Skor \\
\hline 1 & $\begin{array}{l}\text { Siswa dapat menyebutkan jawaban dengan baik dan } \\
\text { benar. }\end{array}$ & 4 \\
\hline 2 & $\begin{array}{l}\text { Siswa dapat menyebutkan jawaban dengan baik dan } \\
\text { benar, tapi kurang lengkap. }\end{array}$ & 3 \\
\hline
\end{tabular}




\begin{tabular}{|l|l|c|}
\hline 3 & $\begin{array}{l}\text { Siswa dapat menyebutkan jawaban tapi salah sebagian } \\
\text { besar. }\end{array}$ & 1 \\
\hline & Skor Maksimum & 8 \\
\hline
\end{tabular}

Nilai $=\frac{\text { total skor perolehan }}{\text { total skor maksimum }} \times 100$

Catatan Guru

\section{Refleksi Guru}

1. Masalah

2. Ide Baru

3. Momen Spesial

Mengetahui,

Makassar, Oktober 2020

Kepala SDN 8 Batu Malang

Guru Kelas V

NIP.

NIP. 


\section{BAB III \\ PENUTUP}

\section{A. Kesimpulan}

Balok adalah bangun ruang yang memiliki tiga pasang sisi yang ukurannya sama dan saling berhadapan serta memiliki bentuk persegi panjang. Untuk menghitung volume atau isi sebuah balok, maka harus diketahui dimensi panjang, lebar, dan tinggi kotak tersebut. Rumus untuk menghitung volume kotak adalah sbb: volume = panjang $\mathrm{x}$ lebar $\mathrm{x}$ tinggi.

Model pembelajaran yang sesuai dengan materi volume balok adalah model pembelajaran numbered heads together. Model Pembelajaran NHT (Numbered Head Together) merupakan salah satu yang termasuk atau tergolong dalam jenis model pembelajaran kooperatif.

Metode yang sesuai dengan materi serta model pembelajaran matematika (volume balok) adalah metode diskusi ialah metode menyajikan pelajaran dimana siswa dihadapkan kepada suatu masalah untuk dipecahkan bersama dalam bentuk kelompok dan juga dapat menyimpulkan hasil diskusinya.

Strategi pembelajaran yang saya pilih yaitu Strategi pembelajaran kooperatif atau SPK, strategi pembelajaran ini yaitu serangkaian kegiatan belajar yang dilakukan siswa dalam kelompok tertentu agar bisa mencapai tujuan pembelajaran yang sudah dirumuskan.

Pendekatan yang saya pilih, yaitu: Pendekatan Student Centered pendekatan student centered mendorong siswa untuk mengerjakan sesuatu sebagai pengalaman praktik dan membangun makna atas pengalaman yang diperolehnya.

\section{B. Saran}

Agar penguasaan materi maupun penerapan materi volume balok lebih kita pahami maka harus dilakukan dengan mencari referensi-referensi yang terjamin. Makalah ini bisa menjadi bahan referensi dalam memenuhi hal tersebut yaitu volume balok. Semoga bisa bermanfaat bagi kita semua dalam memahami materi serta penerapannya. Aamiin. 


\section{Daftar Pustaka}

http://mendidikanakkita.blogspot.com/2010/12/student-centered-learning-scl.html

(Ahad, 07 Februari 2021)

https://jurnalmanajemen.com/strategi-pembelajaran/ (Ahad, 07 Februari 2021)

https://model-modelpembelajaransekolahdasar.blogspot.com/p/blog-

page_1183.html (Ahad, 07 Februari 2021)

https://matematikamudah10.blogspot.com/2019/05/contoh-soal-volume-balok-

dan.html (Ahad, 07 Februari 2021)

https://www.andik.my.id/2020/08/cara-menghitung-volume-balok-dan-

contoh.html (Ahad, 07 Februari 2021)

https://www.silabus.web.id/pembelajaran-diskusi/ (Ahad, 07 Februari 2021)

https://serupa.id/metode-pembelajaran-pengertian-jenis-macam-menurut-para-

ahli/ (Ahad, 07 Februari 2021)

https://fatkhan.web.id/pengertian-metode-diskusi/ (Ahad, 07 Februari 2021)

http://ibnu-soim.blogspot.com/2012/11/strategi-pembelajaran-kooperatif-spk.html http://file.upi.edu/Direktori/FIP/JUR._PEND._LUAR_SEKOLAH/195404021980

112001IHAT_HATIMAH/Pengertian_Pendekatan,_strategi,_metode,_teknik,_ taktik_dan (Ahad, 07 Februari 2021) 